\title{
Perlindungan Hukum Tertanggung Dalam Pembayaran Klaim Asuransi Jiwa
}

\author{
Dudi Badruzaman \\ Fakultas Hukum, STAI Sabili Bandung, Jl. Gagak No.15, Sadang Serang, Bandung, 40133 \\ E-mail: badruzaman.dudi@yahoo.com
}

\begin{abstract}
This research is related to the legal protection of the insured under a life insurance policy claim payments, while the formulation of the problem is how to shape the legal protection of the insured in the payment of life insurance claims; how liability insurance company in the payment of life insurance claims; and what form of dispute resolution that occurs between the insured party to the insurer in the payment of life insurance claims. Results of research is the first form of legal protection of the insured in the payment claim life insurance, where the insurer defaulting form does not implement the achievements in accordance with the agreement in the insurance policy, which does not provide payment of insurance claims to the insured in accordance with the number of insured, the insured can to take legal actions in the form of a lawsuit through the courts and resolve through the existing mechanisms in a life insurance policy. Second, the responsibility of the insurance company in the payment of life insurance claims already regulated in some provisions of the law in both the consumer protection act, the draft civil code, the draft trade law or the law on insurance business. The responsibility is a legal responsibility born of a life insurance agreement. As for the obligation for the insurer to the insured life insurance claims are paid according to the amount of coverage stated in the life insurance policy. Third, the form of settlement of disputes between the insured by the insurer in the payment claim life insurance, in principle procedures for settling disputes between the insured by the insurer in the payment claim life insurance are generally resolved through arbitration institution in accordance with a clause in the policy, but if the policy is not specified institutions which resolve the dispute, it can file a legal action in the District court and the institution of dispute resolution outside the court.
\end{abstract}

Keywords—: hokum; tertanggung; asuransi jiwa; dan pembayaran klaim.

\section{PENDAHULUAN}

Pembangunan nasional meletakan dasar-dasar bagi perjuangan pembangunan bangsa dalam mewujudkan masyarakat untuk meningkatkan ekonomi dan setiap bidang pada umumnya. Pola dasar pembangunan nasional menggariskan apa tujuan pembangunan, merupakan landasan hukum bagi terselenggaranya kegiatan pembangunan itu sendiri. Pembangunan yang sedang dilaksanakan memerlukan peraturan-peraturan hukum yang dapat menunjang serta memberikan arah pembangunan, dimana sejalan dengan bertambahnya kebutuhan-kebutuhan serta perkembangan masyarakat indonesia yang bergerak ke arah perdagangan bebas menuntut usaha pembangunan di bidang hukum.

Hal ini menunjukan bahwa hukum sebagai sarana pembaharuan (agent of change) atau sarana pembangunan diperlukan peranannya dalam pembangunan nasional, sebagaimana menurut Mohtar Kusumaatmadja, bahwa: ${ }^{1}$

"Konsep hukum sebagai sarana pembaharuan adalah hukum dalam arti kaidah atau peraturan hukum yang berfungsi sebagai alat (pengatur) atau saranan pembangunan dalam arti menyalur arah kegiatan manusia ke arah yang dikehendaki oleh pembangunan atau pembaharuan".

Pembangunan di Indonesia merupakan pembangunan manusia yang seutuhnya yaitu pembangunan di segala bidang baik di bidang peningkatan sumber daya manusia maupun peningkatan di bidang sumber daya alam yang bertujuan untuk meningkatkan harkat dan martabat secara adil dan merata guna meningkatkan pembangunan di segala sektor.

Seiring dengan perkembangan jaman serta ditunjang oleh berkembangnya ilmu pengetahuan dan teknologi yang semakin meningkat, maka semakin tinggi pula tingkat kebutuhan hidup manusia, hal ini disebabkan oleh semakin pesatnya perkembangan teknologi dan tingginya persaingan dalam dunia usaha. Disadari kemajuan zaman dan perkembangan teknologi modern yang begitu serba cepat.

Maka tingkat risiko yang terjadi juga terhadap setiap aktifitas manusia juga akan semakin meningkat baik yang mengancam atas diri ataupun harta benda miliknya, sehingga manusia berupaya untuk mengatasinya. Salah satu cara manusia mengatasi risiko adalah melalui peralihan risiko kepada pihak lain dalam hal ini melalui lembaga asuransi. Asuransi sebagai lembaga pengalihan dan pembagian risiko mempunyai kegunaan yang positif baik bagi masyarakat, perusahaan maupun bagi pembangunan negara. Dimana mereka yang mengikatkan diri dalam perjanjian asuransi akan merasa tenteram sebab mendapat perlidungan dari kemungkinan tertimpa suatu kerugian.

Sedangkan bagi suatu perusahaan yang mengalihkan risikonya melalui perjanjian asuransi akan dapat meningkatkan usahanya dan berani menggalang tujuan yang lebih besar. Demikian pula premi-premi yang terkumpulkan dalam suatu perusahaan asuransi dapat diusahakan dan digunakan sebagai dana untuk usaha pembangunan dan hasilnya akan dinikmati oleh

\footnotetext{
${ }^{1}$ Mohtar Kusumaatmadja, "Hukum Masyarakat Dan Pembinaan Hukum Nasional”, Penerbit Bina Cipta. Bandung. 1976. Hlm: 12
} 
Website : http://yustisia.unmermadiun.ac.id/index.php/yustisia

masyarakat. Asuransi merupakan sarana finansial dalam tata kehidupan rumah tangga, baik dalam mengahadapi risiko yang mendasar seperti risiko kematian, atau dalam menghadapi risiko atas harta benda yang dimiliki. Demikian pula dunia usaha dalam menjalankan kegiatannya menghadapi risiko atas harta benda yang mungkin dapat mengganggu kesinambungan usahanya.

Walaupun banyak metode untuk menangani risiko, namun asuransi merupakan metode yang paling banyak dipakai. Asuransi menjanjikan perlindungan kepada pihak tertanggung terhadap risiko yang dihadapi perorangan maupun risiko yang dihadapi perusahaan. Asuransi merupakan suatu perjanjian yang sifatnya konsensual. dimana hal yang telah disepakati dalam perjanjian asuransi dituangkan dalam suatu akta yang disebut polis. Polis tersebut berfungsi sebagai alat bukti dalam penyelenggaraan suatu pertanggungan dalam hal pemberian jaminan ganti kerugian atas terjadinya peristiwa tidak pasti atau risiko yang timbul. Polis pertanggungan memegang peranan penting karena sangat bermanfaat pada waktu pengajuan tuntutan ganti rugi (klaim) atas kontrak prestasinya sebagai akibat dibayarkan premi asuransi pada pihak penanggung.

Dalam hal ini terlihat bahwa para pihak memiliki hak dan kewajiban masing-masing yang harus dipahami, khususnya tertanggung sebagai pemegang polis asuransi jiwa. Terkait dengan pemahaman hak dan kewajiban pemegang polis terdapat unsur-unsur penyebab yang merupakan kurangnya pengetahuan pemegang polis dalam menggunakan hak dan kewajibannya. Dengan adanya hak dan kewajiban tersebut dikenal dengan istilah "Prestasi atau kontra prestasi", maka memungkinkan para pihak untuk melakukan penuntutan atas haknya, di samping itu pula merupakan kewajiban pihak lain untuk memenuhinya. Berdasarkan uraian tersebut yang mendasari penulis ingin melakukan penelitian dengan judul Perlindungan Hukum Tertanggung Dalam Pembayaran Klaim Polis Asuransi Jiwa.

\section{LANDASAN TEORI DAN KONSEPTUAL}

\section{A. Landasan Teori}

Dalam dunia ilmu, teori menempati kedudukan yang sangat penting karena teori memberikan sarana untuk merangkum serta memahami masalah yang dibicarakan secara lebih baik. Hal-hal semula yang nampak tersebar dan berdiri sendiri dapat disatukan dan ditunjukan kaitannya serta merta sama lainnya secara lebih bermakna. ${ }^{2}$

"Kerangka teoritis berisikan teori-teori dan prinsip-prinsip yang berguna sebagai landasan penelitian. Sebagaimana diuraikan oleh Mardalis tentang kerangka teoritis yang dimaksudkan untuk memberikan gambaran atau batasan-batasan tentang teori-teori yang akan dipakai sebagai landasan penelitian yang dilakukan, adalah teori mengenai variabel-variabel permasalahan yang akan diteliti",3

Dalam penelitian ini, adapun landasan teori yang digunakan terkait dengan perlindungan hukum bagi tertanggung dalam pembayaran klaim asuransi jiwa antara lain: teori perlindungan hukum, teori tanggung jawab dan teori penyelesaian sengketa.

\section{B. Teori Perlindungan Hukum}

Salah satu fungsi hukum adalah untuk memberikan perlindungan kepada warga masyarakat, terutama yang berada pada posisi lemah akibat hubungan hukum atau kedudukan yang tidak seimbang. Menurut Philipus M. Hadjon, kaitannya dengan perlindungan hukum kepada rakyat yang harus diberikan oleh pemerintah/penguasa dibedakan atas dua macam perlindungan yakni perlindungan preventif dan refresif: ${ }^{4}$

"Pada perlindungan hukum yang preventif, kepada rakyat diberikan kesempatan untuk mengajukan keberatan (inspraak) atau pendapatnya sebelum suatu keputusan pemerintah mendapat bentuk yang definitif. Dengan demikian, perlindungan hukum yang preventif bertujuan untuk mencegah terjadinya suatu sengketa. Sedangkan sebaliknya perlindungan represif bertujuan untuk menyelesaikan sengketa. Perlindungan preventif sangat besar artinya bagi tindakan pemerintah yang didasarkan kepada kebebasan bertindak karena dengan perlindungan hukum tersebut pemerintah didorong untuk bersikap hati-hati dalam mengambil keputusan. Sedangkan perlindungan hukum yang represif adalah upaya perlidungan hukum yang dilakukan melalui peradilan, baik peradilan umum maupun peradilan administrasi negara".

Perlindungan hukum oleh negara/pemerintah lebih ditekankan pada unsur negara/pemerintah sebagai pemegang kedaulatan. Untuk itu, perlindungan hukum yang diberikan oleh negara/pemerintah kepada warga negaranya dapat dilihat dalam instrumen hukum dan kebijakan yang dikeluarkan oleh pemerintah. ${ }^{5}$

Perlindungan hukum adalah segala upaya yang menjamin adanya kepastian hukum untuk memberi perlindungan kepada konsumen. Kalimat yang menyatakan "segala upaya yang menjamin adanya kepastian hukum”, diharapkan sebagai benteng untuk meniadakan tindakan sewenang-wenang yang merugikan pelaku usaha hanya demi untuk kepentingan perlindungan tertanggung.

\section{Teori Penyelesaian Sengketa}

Menurut Kamus Besar Bahasa Indonesia, sengketa adalah suatu yang menyebabkan perbedaan pendapat, pertengkaran dan perbantahan. ${ }^{6}$ Sengketa merupakan kelanjutan dari konflik, sedangkan konflik itu sendiri adalah suatu perselisihan antara dua

\footnotetext{
22 Khudzaifah Dimyanti, “Teorisasi Hukum”, Penerbit Muhammadiyah Universitas Press. Surakarta. 2004. Hlm: 37

${ }^{3}$ Mardalis, "Metode Penelitian Suatu Pendekatan Proporsional", Penerbit. PT. Bumi aksara. 1989. Hlm: 41

${ }^{4} 4$ Philipus M. Hadjon, "Perlindungan Hukum Bagi Rakyat Di Indonesia” Penerbit Bina Ilmu. Surabaya. 1987. Hlm: 2-3

5 Lalu Husni, "Hukum Penempatan Dan Perlindungan TKI" Penerbit Program Pasca Sarjana Universitas Brawijaya Malang. Malang. 2010. Hlm: 91
} 
pihak, tetapi perselisihan itu hanya dipendam dan tidak diperlihatkan dan apabila perselisihan itu diberitahukan kepada pihal lain maka akan menjadi sengketa. ${ }^{7}$ Konflik merupakan pengindonesiaan kosa kata conflict dalam bahasa Inggris. Selain istilah conflict, bahasa Inggris juga mengenal istilah dispute yang merupakan padanan dari istilah "sengketa" dalam bahasa Indonesia. Keduanya merupakan konsep yang sama yang mendiskripsikan situasi dan kondisi dimana orang-orang yang sedang mengalami perselisihan yang bersifat faktual maupun perselisihan yang ada pada persepsi mereka saja. ${ }^{8}$

Menurut Folberg and Taylor, konflik dapat dibagi menjadi dua kategori, yaitu: ${ }^{9}$

a. Konflik yang terjadi dalam diri induvidu itu sendiri (intrapersonal conflict within the induvidual).

b. Konflik yang terjadi antara induvidu dan induvidu atau antar kelompok (interpersonal).

\section{Unsur-Unsur Asuransi}

Menurut Man Suparman Sastrawidjaya bahwa terdapat beberapa unsur dari asuransi, yaitu:10

1. Merupakan suatu perjanjian;

Perjanjian adalah hubungan hukum antara antara dua pihak atau lebih berdasarkan kata sepakat untuk menimbulkan akibat hukum. Hubungan hukum adalah suatu hubungan yang akibatnya diatur oleh hukum. Kata sepakat dalam suatu perjanjian merupakan unsur esensial. Hal ini merupakan unsur pertama untuk sahnya suatu perjanjian menurut Pasal 1320 KUHPerdata. Karena asuransi adalah perjanjian, maka ketentuan-ketentuan yang berlaku pada perjanjian dalam KUHPerdata berlaku pula untuk perjanjian asuransi selama ketentuan KUHD tidak mengatur yang sebaliknya. ${ }^{10}$

2. Adanya premi;

Premi adalah salah satu unsur penting dalam asuransi karena merupakan kewajiban utama yang wajib dipenuhi oleh tertanggung kepada penanggung. Dalam hubungan hukum asuransi, penanggung menerima pengalihan risiko dari tertanggung dan tertanggung membayar sejumlah premi sebagai imbalannya. Apabila premi tidak dibayar, asuransi dapat dibatalkan atau setidak-tidaknya asuransi tidak berjalan. Premi harus dibayar lebih dahulu oleh tertanggung karena tertanggunglah yang berkepentingan. ${ }^{11}$

3. Adanya kewajiban penanggung untuk memberikan penggantian kepada tertanggung Kewajiban penanggung yang merupakan hak tertanggung, untuk menuntutnya baru timbul apabila peristiwa yang diperjanjikan terjadi.

4. Adanya suatu peristiwa yang belum pasti terjadi (onzeker voorval).

Dalam kaitannya dengan suatu kejadian yang tidak bisa dipastikan tentunya harus dititik beratkan pada bagian yang terpenting dari perjanjian asuransi, yaitu adanya kewajiban bagi pihak asurador untuk membayar uang kepada pihak yang terjamin. Batasan mengenai peristiwa yang tidak pasti, wajib ditinjau dari beberapa segi. Contohnya dalam asuransi kebakaran atau asuransi kecelakaan yang memang benar hal ini tidak bisa dipastikan terjadinya kebakaran atau kecelakaan itu. Perjanjian dalam asuransi sebagai jaminannya adalah meninggal dunianya seseoarang, sedangkan masalah ini sudah ditakdirkan olaeh yang maha kuasa, bahwa manusia tidak akan hidup selamanya. Maka dari itu sesungguhnya yang tidak pasti bukan pada saat kejadian meninggal dunianya manusia akan tetapi kapan orang tersebut akan meninggal dunia. Dan hal ini belum dapat dipastikan. $^{12}$

\section{E. Polis}

Polis merupakan dokumen yang berisi kesepakatan antara pihak tertanggung dan penanggung (pihak asuransi) berkenaan dengan risiko yang hendak dipertanggungkan.

Polis adalah bukti perjanjian penutupan asuransi tersebut. Pasal 255 KUHD menyebutkan bahwa suatu perjanjian asuransi harus dapat dibuat secara tertulis dalam suatu akta yang dinamakan polis. Kesimpulan minimal dari Pasal tersebut dalah bahwa polis merupakan syarat mutlak pada perjanjian asuransi. Akan tetapi kesimpulan tersebut belum maksimal setelah dilakukan penafsiran secara sistematis dengan memperhatikan Pasal 257 dan 258 KUHD. Berdasarkan kedua pasal tersebut dimaksud diperoleh kesimpulan maksimal bahwa polis dalam perjanjian asuransi tidak merupakan syarat mutlak, tetapi hanya merupakan alat bukti saja. Meskipun demikian sesuai dengan asas kebebasan berkontrak yang tersimpul dari Pasal 1338 ayat (1) KUHPerdata diperkenankan saja apabila para pihak memperjanjikan bahwa perjanjian asuransi baru berlangsung setelah polis selesai atau setelah diserahkan kepada tertanggung. Dalam hal yang demikian berarti polis dijadikan sebagai syarat mutlak pada perjanjian asuransi yang bersangkutan. ${ }^{13}$

Undang-undang menentukan bahwa untuk setiap polis harus memenuhi syarat-syarat/isi minimal sebagaimana diatur dalam pasal 256 KUHD sebagai syarat umum, isi polis asuransi menurut Pasal 256 KUHD adalah:

1. Hari ditutupnya pertanggungan.

2. Nama orang yang menutup pertanggungan atas tanggungan sendiri atau atas tanggungan seorang ketiga.

\footnotetext{
${ }^{6}$ Depdikbud RI, Kamus Besar Bahasa Indonesia, Balai Pustaka, Jakarta. 1990. Hlm: 816

7 Rachmadi Usman, "Pilihan Penyelesaian Sengketa Di Luar Pengadilan", PT. Citra Aditya Bhakti, Bandung, 2003. Hlm: 1

${ }^{8} 8$ Takdir Rahmadi, "Mediasi Penyelesaian Sengketa Melalui Pendekatan Mufakat”, Rajawali Pers. Jakarta. 2010. Hlm: 1

9 I Made Widyana, “Alternatif Penyelesaian Sengketa”, Fikahati Aneska, Jakarta. 2009. Hlm: 63.

10 Ibid, Hlm: 16

11 Abdulkadir Muhammad, "Hukum Asuransi Indonesia", Cet. IV, Bandung: Citra Aditya Bakti, 2006, Hlm: 103

${ }_{12}^{12}$ Djoko Prakoso dan I Ketut Murtika, "Hukum Asuransi Indonesia”, Penerbit Bina Aksara. Jakarta. 1987. Hlm: 108

${ }^{13}$ Man Suparman Sastrawidjaja dan Endang, "Hukum Asuransi, Perlindungan Tertanggung, Asuransi Deposito, Usaha Perasuransian”. Penerbit PT. Alumni. Bandung. 2004. Hlm: 144
} 
Website : http://yustisia.unmermadiun.ac.id/index.php/yustisia

3. Suatu uraian yang cukup jelas mengenai barang yang dipertanggungkan.

4. Jumlah uang untuk beberapa diadakan pertanggungan.

5. Bahaya yang ditanggung oleh si penanggung.

6. Saat pada mana bahaya mulai berlaku untuk tanggungan si penanggung dan saat berakhirnya itu.

7. Premi pertanggungan tersebut; dan

8. Pada umumnya, semua keadaan yang kiranya penting bagi si penanggung untuk diketahuinya, dan segala syarat yang diperjanjikan antara para pihak.

\section{F. Premi Asuransi}

Premi asuransi adalah sejumlah uang yang wajib dibayar oleh tertanggung kepada penanggung setiap jangka waktu tertentu, biasanya setiap bulan selama asuransi berlangsung. Besarnya jumlah premi asuransi bergantung pada jumlah asuransi yang disetujui oleh tertanggung pada saat diadakan asuransi. ${ }^{14}$

\section{G. Klaim}

Klaim adalah salah satu fungsi terpenting dari perusahaan asuransi. Adalah essensiil, klaim yang sah itu dibayar dengan segera dan sepenuhnya. Pembayaran klaim yang kurang akan menyebabkan lahirya klaim, sedangkan pembayaran klaim yang berlebihan dapat membawa kebangkrutan. Klaim adalah suatu tuntutan atas suatu hak yang timbul karena persyaratan dalam perjanjian yang ditentukan sebelumnya telah terpenuhi. sedangkan klaim asuransi jiwa adalah suatu tuntutan dari hak pemegang polis atau yang ditunjuk kepada pihak asuransi atas sejumlah pembayaran uang pertanggungan atau harga tunai yang timbul karena syarat-syarat dalam perjanjian asuransinya telah dipenuhi.

\section{III.PEMBAHASAN}

\section{A. Bentuk perlindungan hukum tertanggung dalam pembayaran klaim asuransi jiwa}

\section{Tinjauan Umum Asuransi Jiwa}

Perekonomian negara banyak mempengaruhi perkembangan bisnis asuransi jiwa. Laju pertumbuhan ekonomi nasional menentukan bertambah kuat atau lemahnya daya beli masyarakat, termasuk untuk pembelanjaan untuk polis asuransi jiwa. Dengan demikian terdapat korelasi antara laju pertumbuhan ekonomi dengan pertumbuhan asuransi jiwa, jumlah pertanggungan, dan premi asuransi. Kebutuhan akan jasa perasuransian makin dirasakan, baik oleh perorangan maupun dunia usaha di Indonesia. Asuransi merupakan sarana finansial dalam tata kehidupan rumah tangga, baik menghadapi risiko yang mendasar seperti risiko kematian, atau menghadapi risiko atas harta benda yang dimiliki. Demikian pula dunia usaha dalam menjalankan kegiatannya menghadapi berbagai risiko yang mungkin dapat mengganggu kesinambungan usahanya.

Walau banyak metode untuk menangani risiko, namun asuransi merupakan metode yang paling banyak dipakai. Asuransi menjanjikan perlindungan kepada pihak tertanggung terhadap risiko yang dihadapi perorangan maupun risiko yang dihadapi perusahaan. Di samping itu, usaha perasuransian sebagai salah satu lembaga keuangan menjadi penting peranannya karena dari kegiatan perlindungan risiko, perusahaan asuransi menghimpun dana masyarakat dari penerimaan premi. Perusahaan asuransi merupakan suatu lembaga yang sengaja dirancang dan dibentuk sebagai lembaga pengambil alih dan penerima risiko. Dengan demikian perusahaan asuransi pada dasarnya menawarkan jasa proteksi sebagai produknya kepada masyarakat yang membutuhkannya. Perusahaan asuransi secara spesifik mempunyai ciri dan tujuan operasional, untuk mencapai sasarannya yang khas.

Perusahaan mengusahakan para pelanggannya agar bersedia bergabung dengannya dalam rangka menghadapi risiko-risiko yang mungkin terjadi. Dengan demikian suatu perusahaan asuransi dirancang dan diatur sedemikian rupa agar dapat melaksanakan fungsinya sebagai lembaga pengambil alih dan penerima risiko pihak lain. "Pada sisi lain, perusahaan asuransi adalah suatu perusahaan yang hasil produksinya adalah suatu jasa, dimana jasa tersebut merupakan suatu "janji memberi proteksi" yang merupakan janji untuk memberikan ganti kerugi, apabila nasabah dalam sewaktu-waktu menderita kerugian yang disebabkan karena suatu peristiwa yang sudah diperjanjikan sebelumnya". ${ }^{15}$

\section{Hak dan kewajiban para pihak dalam perjanjian asuransi}

Walaupun perjanjian asuransi merupakan suatu perjanjian khusus karena diatur tersendiri di dalam KUHD, namun dalam hal-hal yang menyangkut syarat sahnya perjanjian dan ketentuan-ketentuan umum lainnya, maka asuransi tunduk pada hukum perjanjian yang diatur dalam KUHPerdata. Hal ini didasarkan pada Pasal 1 KUHD yang menyatakan," Bahwa KUHPerdata pun berlaku untuk hal-hal yang diatur dalam KUHD". Terkait dengan syarat sahnya perjanjian asuransi, tetap mengacu pada syarat sahnya perjanjian yang ada dalam KUHPerdata khususnya Pasal 1320 seperti kesepakatan kedua belah pihak dalam hal ini penanggung dengan tertanggung, kecapakan bertindak seperti sudah dewasa dan tidak berada di bawah pengampuan, obyek tertentu seperti adanya obyek perjanjian asuransi jiwa yaitu pertanggungan atas jiwa serta kausa yang halal seperti tidak bertentangan dengan undang-undang, ketertiban umum dan asusila. Dalam perjanjian asuransi, penanggung berjanji akan

\footnotetext{
14 Abdul kadir Muhammad "Hukum Asuransi Indonesia” Penerbit PT. Citra Aditya Bakti. Bandung. 2002. Hlm: 198

${ }^{15}$ Sri Rejeki Hartono, "Hukum Asuransi Dan Perusahaan Asuransi”, Penerbit Sinar Grafika, Jakarta. 2001. Hlm: 193
} 
membayar kerugian yang disebabkan risiko yang telah diasuransikan kepada tertanggung, sedangkan tertanggung membayar premi secara perodik kepada penanggung. Mengingat setiap perjanjian itu merupakan suatu hubungan hukum maka hak dan kewajiban yang timbul dari suatu perjanjian itu akan dijamin oleh hukum dan undang-undang selama isinya tidak bertentangan dengan hukum, ketertiban, kesusilaan serta memenuhi syarat-syarat perjanjian. Beberapa pasal penting mengenai perjanjian dalam KUHPerdata yang harus diperhatikan dalam perjanjian asuransi, seperti Pasal 1320 KUHPerdata yag mengatur syaratsyarat yang harus dipenuhi dalam suatu perjanjian, yaitu:

1. hal tertentu; Kesepakatan kedua belah pihak;

2. Kecakapan untuk membuat suatu perjanji

3. Suatu hal tertentu;

4. Suatu sebab yang halal.

\section{Bentuk perlindungan hukum tertanggung dalam pembayaran klaim asuransi}

Perlindungan tertanggung adalah istilah yang dipakai untuk menggambarkan perlindungan hukum yang diberikan kepada tertanggung dalam usahanya untuk memenuhi kebutuhannya dari hal-hal yang dapat merugikan tertanggung itu sendiri. Dalam bidang hukum tertanggung bisa dikatakan sebagai konsumen karena dalam undang-undang perlindungan konsumen, konsumen adalah setiap pengguna barang dan/atau jasa, istilah ini masih relatif baru, khususnya di Indonesia, sedangkan di negara maju, hal ini mulai dibicarakan bersamaan dengan berkembangnya industri dan teknologi.

Dengan pemahaman bahwa perlindungan konsumen mempersoalkan perlindungan (hukum) yang diberikan kepada konsumen dalam usahanya untuk memperoleh barang dan jasa dari kemungkinan timbulnya kerugian karena penggunaannya, maka hukum perlindungan konsumen dapat dikatakan sebagai hukum yang mengantur tentang pemberian perlindungan kepada konsumen (tertanggung) dalam rangka pemenuhan kebutuhannya sebagai konsumen. Dengan demikian, hukum perlindungan konsumen mengatur hak dan kewajiban konsumen, hak dan kewajiban produsen, serta cara-cara

\section{B. Tanggung jawab perusahaan asuransi dalam Pembayaran klaim asuransi jiwa}

\section{Prinsip Tanggung Jawab}

Ada dua istilah yang menunjuk pada pertanggungjawaban dalam kamus hukum, yaitu liability dan responsibility. Istilah liability menunjuk pada pertanggungjawaban hukum, yaitu tanggung gugat akibat atas kesalahan yang dilakukan oleh subyek hukum sedangkan istilah responsibility menunjuk pada pertanggungjawaban politik"

Secara umum prinsip tanggung jawab dalam hukum dapat dibedakan sebagai berikut: ${ }^{16}$

1. Prinsip Tanggung Jawab Berdasarkan Unsur Kesalahan (Fault Liability atau Liability Based On Fault) dimana suatu prinsip yang cukup umum berlaku dalam hukum pidana dan perdata. Dalam KUHPerdata, khususnya Pasal 1365, 1366, dan 1367, prinsip ini dipegang secara teguh. Prinsip ini menyatakan, seorang baru dapat dimintakan pertanggungjawaban secara hukum jika ada unsur kesalahan yang dilakukannya. Pasal 1365 KUHPerdata, yang lazim dikenal sebagai pasal tentang perbuatan melawa hukum, mengharuskan terpenuhinya empat unsur pokok yaitu (1) adanya perbuatan,

2. Adanya unsur kesalahan, (3) adanya kerugian yag diderita, (4) adanya hubungan kausalitas antara kesalahan dan kerugian. 2. Prinsip Praduga Untuk Selalu Bertanggung Jawab (Presumption Of Liability Principle), dimana prinsip ini menyatakan bahwa tergugat selalu dianggap bertanggung jawab sampai ia dapat membuktikan bahwa ia tidak bersalah. Kata "dianggap" pada prinsip "Presumption Of Liability" adalah penting, karena ada kemungkinan tergugat membebaskan diri dari tanggung jawab, yaitu dalam hal membuktikan bahwa ia telah "mengambil" semua tindakan yang diperlukan untuk menghindarkan terjadinya kerugian. Jadi beban pembuktian ada pada si tergugat.

3. Prinsip Praduga Untuk Tidak Selalu Bertanggung Jawab (Presumption Of Non Liability Principle), prinsip ini adalah kebalikan dari prinsip yang kedua, prinsip praduga untuk tidak selalu bertanggungjawab hanya dikenal dalam lingkup transaksi konsumen yang sangat terbatas. Contoh dari penerapan prinsip ini adalah pada hukum pengangkutan. Kehilangan atau kerusakan pada bagasi kabin atau bagasi tangan, yang biasanya dibawah dan diawasi oleh penumpang adalah tanggung jawab dari penumpang.

4. Prinsip Tanggung Jawab Mutlak (Srict Liability), prinsip tanggung jawab mutlak sering diidentikan dengan prinsip tanggung jawab absolut (Absolut Liability) dimana prinsip tanggung jawab tanpa kesalahan dan tidak ada pengecualian. Kendati demikian adapula para ahli yang menbedakan kedua terminologi di atas. Ada pendapat yang menyatakan, strict liability adalah prinsip tanggung jawab yang menetapkan kesalahan tidak sebagai faktor yang menetukan. Namun ada pengecualian-pengecualian yang memungkimkan untuk dibebaskan dari tanggung jawab, misalnya kedaan force majeur. Sebaliknya absolut liability adalah prinsip tanggung jawab tanpa kesalahan dan tidak ada pengecualian.

5. Prinsip Tanggung Jawab Dengan Pembatasan (Limitation Of Liability Principle), prinsip ini sangat disenangi oleh pelaku usaha untuk dicantumkan sebagai klausula eksenorasi dalam perjanjian standar yang dibuatnya. Dari beberapa prinsip tanggung jawab di atas, yang terkait dengan tanggung jawab penanggung terhadap tertanggung dalam perjanjian asuransi jiwa adalah prinsip tanggung jawab dengan pembatasan (Limitation Of Liability Principle), dimana berdasarkan prinsip ini bahwa penanggung bertanggung jawab terhadap tertanggung sebatas apa yang diperjanjikan dalam polis asuransi, sehingga

\footnotetext{
${ }^{16} 67$ Heni Sekartati, “Aspek Hukum Perlindungan Konsumen Dalam Transaksi Multi Level Marketing” Fakultas Hukum Universitas Sumatera Utara. 2007. Hlm: 35
} 
tertanggung, tertunjuk atau penikmat tidak dapat menuntut tanggung jawab kepada penanggung yang melebihi jumlah pertanggungan yang ada ketentuan polis asuransi jiwa tersebut.

Pertanggungjawaban hukum yang dapat dikenakan kepada pelaku usaha apabila dalam melakukan usahanya masih menyimpang atau tidak sesuai dengan ketentuan ini: ${ }^{17}$

\section{Contractual liability}

Contractual liability atau pertanggungjawaban kontraktual merupakan pertanggungjawaban perdata atas dasar perjanjian/ kontrak dari pelaku usaha (baik barang maupun jasa), atas kerugian yang dialami oleh konsumen atas mengkonsumsi atau menggunakan barang dan/atau jasa yang diberikannya.

\section{Product liability}

Product liability merupakan tanggung jawab perdata secara langsung (strict liability) dari pelaku usaha (produsen barang) atas kerugian yang dialami konsumen akibat mengkonsumsi barang yang dihasilkan. Inti dari strict liability yaitu tanggung jawab berdasarkan perbuatan melawan hukum. Product liability akan digunakan oleh konsumen untuk memperoleh ganti rugi secara langsung dari produsen (barang) sekalipun konsumen tidak mempunyai hubungan kontraktual (privity of contract) dengan produsen tersebut.

\section{Criminal liability}

Criminal liability yaitu tanggung jawab pidana dari pelaku usaha (baik barang atau jasa) atas terganggunya keselamatan dan keamanan masyarakat (konsumen), selain sanksi pidana, terhadap pelaku usaha masih dapat dikenakan hukuman pidana tambahan, berupa:

a) Perampasan barang tertentu

b) Pengumuman putusan hakim

c) Pembayaran ganti rugi

d) Perintah penghentian kegiatan tertentu yang menyebabkan timbulnya kerugian konsumen;

e) Kewajiban penarikan barang dan/atau jasa dari peredaran

f) Pencabutan ijin usaha.

Berdasarkan beberapa uraian di atas, bahwa tanggung jawab hukum yang ditujukan kepada penanggung dalam hal ini perusahaan asuransi jiwa atas pembayaran klaim kepada tertanggung adalah tanggung jawab berdasarkan kontraktual (Contractual Laibility). Berdasarkan tanggung jawab tersebut perusahaan asuransi selaku penanggung bertanggung jawab atas pembayaran klaim asuransi jiwa yang menjadi hak tertanggung berdasarkan perjanjian asuransi.

\section{Tanggung Jawab Perusahaan Asuransi Dalam Pembayaran Klaim Asuransi Jiwa}

Perjanjian asuransi, penanggung berjanji akan membayar kerugian yang disebabkan risiko yang telah diasuransikan kepada tertanggung, sedangkan tertanggung membayar premi secara perodik kepada penanggung. Mengingat setiap perjanjian itu merupakan suatu hubungan hukum maka hak dan kewajiban yang timbul dari suatu perjanjian itu akan dijamin oleh hukum dan undang-undang selama isinya tidak bertentangan dengan hukum, ketertiba, kesulsilaan serta memenuhi syarat-syarat perjanjian. Walaupun perjanjian asuransi merupakan suatu perjanjian khusus karena diatur tersendiri di dalam KUHD, namun dalam halhal yang menyangkut syarat sahnya perjanjian dan ketentuan-ketentuan umum lainnya, maka asuransi tunduk pada hukum perjanjian yang diatur dalam KUHPerdata. Hal ini didasarkan pada Pasal 1 KUHD yang menyatakan," Bahwa KUHPerdata pun berlaku untuk hal-hal yang diatur dalam KUHD". Konsekuensinya, apabila para pihak dalam perjanjian asuransi telah menyepakati syarat-syarat yang terdapat dalam polis asuransi, maka menurut hukum mereka harus mematuhi dan melaksanakannya. Tetapi syarat-syarat yang tercantum dalam polis tersebut hanya berlaku bagi penanggung dan tertanggung. Semua perjanjian yang dibuat oleh penanggung dengan tertanggung tertuang dalam polis asuransi. Dimana telah diatur oleh ketentuan-ketentuan hukum yang berlaku dan apabila dalam perjanjian tersebut salah satu pihak wanprestasi maka perjanjian tersebut dapat dibatalkan oleh pihak-pihak dan sanksi-sanksi hukum dapat diterapkan sesuai dengan hukum yang berlaku.

Dengan meninggalnya tertanggung itu, maka akan mengakibatkan hilangnya sumber penghasilan bagi pihak yang berkepentingan dan oleh sebab itu diperlukan bantuan sementara yang akan berguna untuk jangka waktu tertentu. Bantuan tersebut dalam asuransi jiwa adalah pembayaran sejumlah uang asuransi (uang pertanggungan) oleh perusahaan asuransi kepada pemegang polis atau kepada pihak yang menerima manfaat setelah syarat-syarat dalam perjanjian asuransi itu dipenuhi sesuai dengan kondisi polisnya. Pembayaran uang pertanggungan ini adalah sesuai dengan perjanjian asuransi jiwa yaitu diterimanya risiko dari si tertanggung, dalam hal ini ialah meninggalnya si tertanggung.

Untuk mendapatkan uang pertanggungan itu diisyaratkan bahwa pihak pemegang polis atau yang menerima manfaat perlu menyampaikan laporan yang dalam asuransi disebut dengan tuntutan (klaim) kepada pihak perusahaan asuransi jiwa. Jadi klaim itu adalah sebuah tuntutan dari pemegang polis atau yang menerima manfaat atas uang pertanggungan, yang timbul karena syarat-syarat yang ditentukan dalam perjanjian telah dipenuhi.

\footnotetext{
${ }^{17}$ Johannes Gunawan, “Tanggung Jawab Pelaku Usaha Berdasarkan Undang-Undang Nomor 8 Tahun 1999”, Jurnal Hukum Bisnis. Volume 8. 1999.
} 


\section{Tanggung Jawab Perusahaan Asuransi Berdasarkan Kitab Undang-Undang Hukum Perdata}

Sistem pengaturan hukum kontrak adalah sistem terbuka (open system). Artinya bahwa setiap orang bebas untuk mengadakan perjanjian baik yang suda diatur maupun yang belum diatur di dalam undang-undang. Hal ini dapat disimpulkan dari ketentuan yang tercantum dalam Pasal 1338 ayat (1) KUHPerdata, yang berbunyi, "semua perjanjian yang dibuat secara sah berlaku sebagai undang-undang bagi mereka yang membuatnya".

Ketentuan Pasal 1338 ayat (1) KUHPerdata memberikan kebebasan kepada para pihak untuk:

a) Membuat atau tidak membuat suatu perjanjian;

b) Mengadakan perjanjian dengan siapapun;

c) Menentukan isi perjanjian, pelaksanaan dan persyaratannya;

d) Menentukannya bentuk perjanjian apakah tertulis atau lisan.

Dengan adanya asas kebebasan berkontrak tersebut setiap orang bebas untuk memperoleh apa yang dikehendakinya termasuk mengadakan perjanjian asuransi jiwa. Selain kebebasan berkontrak yang terpenting lagi dalam hukum perjanjian adalah adanya asas pacta sunt servanda atau disebut juga dengan asas kepastian hukum. Asas ini berhubungan dengan akibat perjanjian, dimana hakim atau pihak ketiga harus menghormati substansi perjanjian yang dibuat oleh para pihak sebagaimana layaknya sebuah undang-undang. Mereka tidak boleh intervensi terhadap substansi perjanjian yang dibaut oleh para pihak.

\section{Bentuk Penyelesaian Sengketa Antara Pihak Tertanggung Dengan Pihak Penanggung Dalam Pembayaran Klaim Asuransi Jiwa}

\section{Faktor Penyebab Terjadinya Sengketa}

Pengertian sengketa dalam kamus Bahasa Indonesia adalah pertentangan atau konflik. Konflik berarti adanya oposisi atau pertentangan antara orang-orang, kelompok-kelompok, atau organisasi-organisasi terhadap satu obyek permasalahan. Pertentangan atau konflik yang terjadi antara individu-individu atau kelompok-kelompok yang mempunyai hubungan atau kepentingan yang sama atas suatu obyek kepemilikan, yang menimbulkan akibat hukum antara satu dengan yang lain. Sengketa adalah pertentangan antara dua pihak atau lebih yang berawal dari persepsi yang berbeda tentang suatu kepentingan atau hak milik yang dapat menimbulkan akibat hukum bagi keduanya. Dalam perjanjian asuransi jiwa, antara tertanggung dengan penanggung sering terjadi sengketa terutama terkait pembayaran klaim asuransi jiwa. Pada umumnya penyebab dari timbulnya sengketa dalam pembayaran klaim asuransi jiwa disebabkan oleh beberapa faktor:

\section{a. Tertanggung}

Pada umumnya salah faktor yang menyebabkan tertanggung sulit untuk mendapatkan klaim pembayaran asuransi jiwa adalah penyebabnya adalah dari pihak tertanggung sendiri, antara lain:

1) Tidak memberikan keterangan-keterangan yang diperlukan penaggung dalam hal-hal yang perlu diberitahukan dengan benar;

2) Tidak membayarkan premi asuransi sesuai dengan yang diperjanjika.

3) Tidak melengkapi surat-surat yang diperlukan penaggung baik dalam masa asuransi maupun dalam mengajukan klaim.

4) Penikmat juga sering terlambat menyampaikan klaim asuransi ketika tertanggung meninggal dunia, sehingga kadang-kadang penyampaian klaim sudah melewati tanggal pengajuan klaim.

b. Penanggung

Sedangkan faktor penyebab sulitnya pengajuan klaim asuransi jiwa yang disebabkan oleh penanggung, antara lain:

1) Tidak menjelaskan isi dari polis asuransi kepada tertanggung, sehingga tertanggung kadang-kadang tidak mengerti tentang isi polis asuransi yang menyebabkan multi penafsiran antara tertanggung dengan penanggung.

2) Tidak membayar uang pertanggungan kepada pemegang polis apabila masa kontrak telah berakhir dan kepada seorang yang ditunjuk atau penerima manfaat apabila tertanggung meninggal dunia.

3) Tidak membayar nilai tunai polis kepada pemegang polis yang mengakhiri perjanjian asuransi sebelum masa pertanggungan berakhir.

c. Penerima manfaat

Pada umumnya penerima manfaat sulit untuk menerima hak atas uang pertanggungan, karena disebabkan:

1) Tidak memberitahukan kepada penanggung tentang kematian tertanggung;

2) Tidak dapat membuktikan dapat ditagihnya uang dari penaggung;

3) Tidak dapat membuktikan haknya untuk menerima uang pertanggungan; serta

4) Tidak dapat menunjukan kwitansi pembayaran premi yang terakhir.

Sehingga dari beberapa faktor di atas, maka sering timbul keluhan-keluhan antara tertanggung menganggap haknya dilanggar oleh pihak penanggung. Setelah tertanggung menyampaikan keluhan-keluhannya, maka tahap selanjutnya pihak penaggung menanggapi dengan menunjukkan reaksi negatif atas keluhan-keluhan yang berujung pada situasi konflik. Setelah konflik-konflik makin meluas dan sampai di bawah ke lembaga peradilan maka situasi akan berubah menjadi sengketa. Jadi sengketa merupakan lanjutan dari keluhan dan konflik. 
Menurut Nader dan Todd, konflik yang terjadi dalam masyarakat pada dasarnya melalui tahapan-tahapan konflik (conflict stages), yaitu:

"Pada tahap pertama,konflik berawal dari munculnya keluhan-keluhan (grievance) dari salah satu terhadap pihak yang lain (individu atau kelompok), karena pihak yang mengeluh merasa hak-haknya dilanggar, diperlakukan secara tidak wajar, kasar, dipersalahkan, diinjak harga dirinya, dirusak nama baiknya, dilukai hatinya, dll. Kondisi awal seperti ini disebut sebagai prakonflik (pra-conflict stage) yang cendrung mengarah kepada konfrontasi yang bersifat monadik (monadic). Pada tahap kedua apabila kemudian pihak yang lain menunjukkan reaksi negatif berupa sikap bermusuhan atas munculnya keluhan-keluhan dari pihak yang pertama, maka kondisi ini meningkat eskalasinya menjadi situasi konflik (conflic stage), sehingga konfrontasi antar pihak berlangsung secara diadik (diadic). Dan Pada tahap ketiga, apabila konflik antar pihak-pihak tersebut ditunjukkan dan dibawa ke arena publik (masyarakat), dan diproses menjadi kasus perselisihan antar instusi penyelesaian sengketa tertentu dengan melibatkan pihak ketiga maka situasinya meningkat menjadi sengketa (dispute stage) dan sifat konfrontasi antar pihakpihak yang berselisih menjadi triadik (triadic).

Berdasarkan uraian di atas, bahwa penyebab terjadinya sengketa antara penanggung dengan tertanggung atau penikmat disebabkan oleh tertanggung atau penikmat itu sendiri maupun dari pihak penanggung. Dari tidak melaksanakan hak dan kewajiban tersebut menyebabkan timbulnya sengketa dalam pengajuan klaim asuransi.

\section{Bentuk Penyelesaian Sengketa Pada Umumnya}

Dalam kehidupan sehari-hari, terlebih di dunia bisnis setiap orang tentu menghendaki segala sesuatu berjalan dengan baik tanpa masalah apapun terlebih sengketa. Akan tetapi kenyataannya hidup ini tidak pernah luput dari masalhanya masalah yang muncul melainkan sengketa juga.

Beberapa diantara masalah atau sengketa itu hadir tanpa dikehendaki atau dicegah oleh seseorang sebab bermula dari pihak lain. Dengan demikian, tidak ada seorangpun yang dapat memastikan dirinya akan senantiasa luput dari sengketa. Dengan mengetahui beberapa segi penting penyelesaian sengketa, para pelaku bisnis diharapkan akan memiliki dasar pertimbangan untuk menggunakan penyelesaian sengketa secara tepat. Kapan harus menggunakan cara-cara penyelesaian sengketa dan kapan harus menghindari. Kalaupun sudah yakin perlu memanfaatkan penyelesaian sengketa masih harus memilih cara penyelesaian sengketa yang paling tepat diantara cara-cara yang ada. Kelancaran penyelesaian sengketa melalui pengadilan dipengaruhi berbagai faktor, antara lain kemerdekaan kekuasaan kehakiman. Kekuasaan kehakiman yang merdeka mengandung beberapa tujuan dasar yaitu: ${ }^{18}$

a. Sebagai bagian dari sistem pemisahan atau pembagian kekuasaan diantara badan-badan penyelenggara negara. Kekuasaan kehakiman yang merdeka diperlukan untuk menjamin dan kebebasana induvidu.

b. Kekuasaan hakim yang merdeka diperlukan untuk mencegah penyelenggaraan pemerintahan bertindak tak semena-mena dan menindas.

c. Kekuasaan hakim yang merdeka diperlukan untuk dapat menilai keabsahan secara hukum tindakan pemerintahan atau suatu peraturan perundang-undangan sehingga sistem hukum dapat dijalankan atau ditegakkan dengan baik.

\section{Penyelesaian sengketa di luar pengadilan (Non Litigasi)}

Sebagaimana telah diuraikan di atas, penyelesaian sengketa melalui pengadilan masih menyisakan berbagai persoalan sehingga perlu ada cara-cara lain di luar pengadilan, dapat berupa arbitrase maupun beberapa alternatif penyelesaian sengketa lain, seperti konsultasi, negosiasi, mediasi, atau konsiliasi. Keberadaan upaya-upaya penyelesaian ini sebenarnya sudah sejak lama, tetapi semakin populer setelah diberlakukan Undang-Undang Nomor 30 Tahun 1999 tentang Arbitrase dan Alternatif Penyelesaian Sengketa. Dalam undang-undang ini dikemukakan bahwa arbitrase adalah cara penyelesaian suatu sengketa perdata di luar peradilan umum yang didasarkan pada perjanjian arbitrase yang dibuat secara tertulis oleh para pihak yang bersengketa. Perjanjian arbitrase adalah suatu kesepakatan berupa klausula arbitrase yang tercantum dalam suatu perjanjian tertulis yang dibuat para pihak sebelum timbul sengketa, atau perjanjian arbitrase tersendiri yang dibuat para pihak setelah timbul sengketa. Pengadilan negeri tidak berwenang untuk mengadili sengketa para pihak yang telah terikat dalam perjanjian arbitrase. Lembaga Arbitrase adalah badan yang dipilih leh para pihak yang bersengketa untuk memberikan putusan mengenai sengketa tertentu. Lembaga tersebut juga dapat memberikan pendapat yang mengikat mengenai suatu hubungan hukum tertentu sebelum timbul sengketa. Sengketa yang dapat diselesaikan melalui lembaga arbitrase hanya sengketa di bidang perdagangan dan mengenai hak yang menurut hukum dan peraturan perundang-undangan dikuasai sepenuhnya oleh pihak yang bersengketa. Sengketa yang tidak dapat diselesaikan melalui arbitrase adalah sengketa yang menurut peraturan perundang-undangan tidak dapat diadakan perdamaian.

Pada umumnya lembaga arbitrase mempunyai kelebihan bila dibandingkan dengan lembaga peradilan, kelebihan tersebut antara lain:

1. Kerahasiaan dijamin para pihak yang bersengketa;

2. Dapat dihindari kelambatan yang diakibatkan karena hal prosedur dan administrasi;

\footnotetext{
${ }^{18}$ Budiman N.P.D Sinaga, "Hukum Kontrak Dan Penyelesaian Sengketa Dari Perspektif Sekretaris” penerbit PT. Raja Grafindo Persada. Jakarta. 2005. Hlm: 32
} 
3. Para pihak memilih arbiter yang menurut keyakinannya mempunyai pengetahuan, pengalaman, serta latar belakang yang memadai mengenai masalah yang dipersengketakan, jujur dan adil;

4. Para pihak dapat menentukan pilihan hukum untuk menyelesaikan masalah, proses, dan tempat penyelenggaan arbitrase;

5. Putusan arbitrase merupakan putusan yang mengikat para pihak dan melalui tata cara atau prosedur yang sederhana dan langsung dapat dilaksanakan. Walaupun dalam kenyataanya, apa yang disebutkan tersebut tidak semuanya betul, karena di beberapa negara terkadang proses peradilan dapat lebih cepat dari pada proses arbitrase. Kelebihan arbitrase terhadap pengadilan yang paling dirasakan adalah sifat kerahasiaannya karena hasil putusanannya tidak dipublikasikan. Sehingga penyelesaian sengketa melalui abitrase lebih diminati dari pada model litigasi atau peradilan terutama untuk kontrak bisnis bersifat internsional. ${ }^{19}$

\section{IV.PENUTUP}

Setelah melalui pembahasan dan pengkajian dalam bab-bab terdahulu, dapat disimpulkan sebagai berikut:

1. Bentuk perlindungan hukum tertanggung dalam pembayaran klaim asuransi jiwa, apabila pihak penanggung wanprestasi berupa tidak melaksanakan prestasi sesuai dengan yang diperjanjikan dalam polis asuransi, yaitu tidak memberikan pembayaran klaim asuransi kepada pihak tertanggung sesuai dengan jumlah pertanggungan, maka tertanggung dapat melakukan upaya hukum berupa gugatan melalui pengadilan maupun menyelesaikan melalui mekanisme yang ada dalam polis asuransi jiwa.

2. Tanggung jawab perusahaan asuransi dalam pembayaran klaim asuransi jiwa sudah diatur dalam beberapa ketentuan hukum baik dalam Undang-Undang Perlindungan Konsumen, Kitab Undang-Undang Hukum Perdata, Kitab Undang-Undang Hukum Dagang maupun dalam Undang-Undang Tentang Usaha Perasuransian. Tanggung jawab tersebut merupakan suatu tanggung jawab hukum yang lahir dari perjanjian asuransi jiwa. Adapun kewajiban kewajiban bagi pihak penanggung terhadap tertanggung adalah membayarkan klaim asuransi jiwa sesuai dengan jumlah pertanggungan yang tercantum dalam polis asuransi jiwa tersebut.

Bentuk penyelesaian sengketa antara tertanggung dengan penanggung dalam pembayaran klaim asuransi jiwa, pada prinsipnya prosedur penyelesaian sengketa antara tertanggung dengan penanggung dalam pembayaran klaim asuransi jiwa pada umumnya diselesaikan melalui lembaga arbitrase sesuai dengan klausula dalam polis, akan tetapi apabila dalam polis tersebut tidak ditentukan lembaga mana yang menyelesaikan sengketa maka dapat mengajukan upaya hukum di Pengadilan Negeri maupun lembaga penyelesaian sengketa di luar pengadilan.

\section{DAFTAR PUSTAKA}

\section{A. Buku}

Abdulkadir Muhammad, "Hukum Asuransi Indonesia", Cet. IV, Bandung: Citra Aditya Bakti, 2006. , "Hukum Asuransi Indonesia" Penerbit PT. Citra Aditya Bakti. Bandung. 2002.

Basuki Rekso Wibowo, "Menyelesaikan Sengketa Bisnis Di Luar Pengadilan” (Pidato). Disampaikan pada Pengukuhan Guru Besar dalam Bidang Ilmu Hukum, Fakultas Hukum Universitas Airlangga Surabaya. 17 Desember 2005.

Budiman N.P.D Sinaga, "Hukum Kontrak Dan Penyelesaian Sengketa Dari Perspektif Sekretaris" Penerbit PT. Raja Grafindo Persada. Jakarta. 2005.

Djoko Prakoso dan I Ketut Murtika, "Hukum Asuransi Indonesia", Penerbit Bina Aksara. Jakarta. 1987.

Herman Darmawin, "Manajemen Asuransi" Penerbit Bumi Aksara, Jakarta. 2006.

Janus Sidabalok, "Hukum Perlindungan Konsumen Di Indonesia”, Penerbit PT. Citra Adytia Bakti. Bandung, 2010.

Johannes Gunawan, "Tanggung Jawab Pelaku Usaha Berdasarkan Undang-Undang Nomor 8 Tahun 1999”,

Jurnal Hukum Bisnis. Volume 8. 1999. Joni Emirzon, “Alternatif Penyelesaian Sengketa Di Luar Pengadilan (Negosiasi, Mediasi, Konsiliasi, dan Arbitrase)", Jakarta, 2001.

Lalu Husni "Hukum Penempatan Dan Perlindungan TKI” Cetakan Pertama Penerbit Program Pasca Sarjana Universitas Brawijaya Malang. Malang. 2010.

Man Suparman Sastrawidjaja dan Endang, "Hukum Asuransi, Perlindungan Tertanggung, Asuransi Deposito, Usaha Perasuransian". Penerbit PT. Alumni. Bandung. 2004 Sastrawidjaja, "Aspek-aspek Hukum Asuransi dan Surat Berharga". Bandung: Alumni. 1997.

Marzuki Ahmad, "Perlindungan Konsumen Di Indonesia" Media Indonesia, Edisi 6 april, Jakarta. 2007.

Mukti Fajar ND dan Yulianto Achmad "Dualisme Penelitian Hukum Normatif Dan Empiris" Cetakan I Penerbit Pustaka Pelajar.Yokyakarta. 2010.

Mohtar Kusumaatmadja, "Hukum Masyarakat Dan Pembinaan Hukum Nasional”, Penerbit Bina Cipta. Bandung. 1976.

M. Yahya Harahap, "Segi-Segi Hukum Perjanjian”, Penerbit Alumni, Bandung, 1986.

Peter Mahmud Marzuki, "Batas-Batas Kebebesan Berkontrak" Yudika, Vol. 18 No. 3 Mei 2003.

Philipus M. Hadjon, "Perlindungan Hukum Dalam Negara Hukum Pancasila” Simposium Politik, Hak Asasi Manusia Dan Pembangunan Hukum, lustrum VIII, Universitas Airlangga, Surabaya. 1994.

"Perlindungan Hukum Bagi Rakyat Di Indonesia" Bina Ilmu, Surabaya, 1987.

Purwosucipto dalam Abdulkadir Muhammad, "Hukum Asuransi Di Indonesia”, Penerbit PT. Citra Aditya Bakti. Bandung. 2006.

Wirjono Projodikoro, "Hukum Asuransi di Indonesia". Intermasa. Jakarta. 1996.

Salim HS, dkk. "Perancangan Kontrak dan Memorandum Of Undestanding" SinarGrafika. Jakarta. 2007.

"Pengantar Hukum Perdata Tertulis (BW)". Cetakan kelima. Sinar Grafika. Jakarta. 2008.

"Hukum Kontrak Teori Dan Teknik Penyusunan Kontrak" Cetakan keempat. Penerbit Sinar Grafika. Jakarta. 2006.

Sri Rejeki Hartono, "Hukum Asuransi Dan Perusahaan Asuransi”, Penerbit Sinar Grafika, Jakarta. 2001.

Sri Wahyuni, "Hak Konsumen Di Indonesia" Pustaka Bangsa, Cetakan Ke 1, Jakarta 2007.

Subekti, "Hukum Perjanjian” Penerbit Intermesa. Jakarta. 2002.

\footnotetext{
${ }^{19}$ Suyud Margono, “ADR (Alternative Dispute Resolution) Dan Arbitrase Proses Pelembagaan Dan Proses Hukum”, Penerbit Ghalia Indonesia, Bogor Selatan.
} 2004. Hlm: 20. 
Website : http://yustisia.unmermadiun.ac.id/index.php/yustisia

Sudikno Mertokusumo, “Mengenal Hukum”. Penerbit Liberty. Yokyakarta. 1986.

Suyud Margono, “ADR dan Arbitrase: Proses Pelembagaan dan Aspek Hukum”, Jakarta, Ghalia Indonesia. 2000. 2004.

Yahman, "Karakteristik Wanprestasi Dan Tindak Pidana Penipuan Yang Lahir Dari Hubungan Kontraktual”, Penerbit Perstasi Pustaka, Jakarta, 2011.

Yohanes Sogar Simamora, "Hukum Perjanjian, Prinsip Kontrak Pengadaan Barang Dan Jasa Oleh Pemerintah", Cetakan Pertama, Penerbit Laksbang Pressindo. Yokyakarta. 2009.

\section{B. Perundang-Undangan Kitab}

Undang-Undang Hukum Dagang.

Kitab Undang-Undang Hukum Perdata.

Undang-Undang Nomor 2 Tahun 1992 tentang Usaha Perasuransian (Lembaran Negara Republik Indonesia Tahun 1992 Nomor 13 dan Tambahan Lembaran Negara 3467).

Peraturan Pemerintah Nomor 63 Tahun 1999 tentang Penyelenggaraan Usaha Perasuransian (Lembaran Negara Republik Indonesia Tahun 1999 Nomor 188 dan Tambahan Lembaran Negara 3861).

Keputusan Menteri Keuangan RI No. 979/KMK. 01111985 tentang Perijinan Agen Asuransi Jiwa di Indonesia

\section{Internet}

http://www.google.com. Andang Darmawan, Tinjauan tentang penyelesaian klaim dalam Asuransi Jiwa pada PT. Asuransi Wana Artha Life Surakarta, Surakarta: 2008.

http://www.google.com. Hendri Risjawan, definisi dan Tujuan Asuransi, 2006

http://kumpulan-teori-skripsi.blogspot.com/2011/09/teori-keadilan aristoteles.html.

http://seputar-Indonesia.com 2007, diakses tanggal 18 Juli 2012.

http//APS\%20asuransi\%20melalui\%20mediasi-Civics yang diakses pada tanggal 2018 Juli 2012. 